\title{
8
}
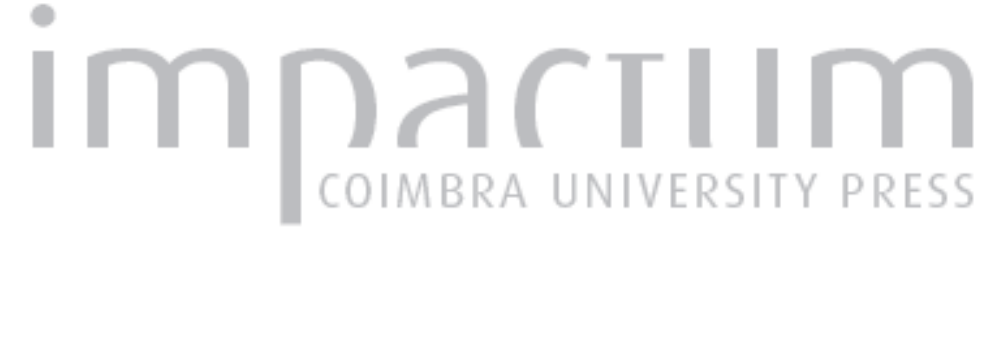

\section{Entre a tradição e a inovação: a agricultura da Beira Alta nos séculos XVIII e XIX}

\author{
Autor(es): $\quad$ Oliveira, João Nunes de
}
Publicado por: Instituto de História Económica e Social, Faculdade de Letras da Universidade de Coimbra

URL persistente:

URI:http://hdl.handle.net/10316.2/9704

DOI:

DOI:http://dx.doi.org/10.14195/0870-4147_41_4

Accessed : $\quad$ 26-Apr-2023 14:12:36

A navegação consulta e descarregamento dos títulos inseridos nas Bibliotecas Digitais UC Digitalis, UC Pombalina e UC Impactum, pressupõem a aceitação plena e sem reservas dos Termos e Condições de Uso destas Bibliotecas Digitais, disponíveis em https://digitalis.uc.pt/pt-pt/termos.

Conforme exposto nos referidos Termos e Condições de Uso, o descarregamento de títulos de acesso restrito requer uma licença válida de autorização devendo o utilizador aceder ao(s) documento(s) a partir de um endereço de IP da instituição detentora da supramencionada licença.

Ao utilizador é apenas permitido o descarregamento para uso pessoal, pelo que o emprego do(s) título(s) descarregado(s) para outro fim, designadamente comercial, carece de autorização do respetivo autor ou editor da obra.

Na medida em que todas as obras da UC Digitalis se encontram protegidas pelo Código do Direito de Autor e Direitos Conexos e demais legislação aplicável, toda a cópia, parcial ou total, deste documento, nos casos em que é legalmente admitida, deverá conter ou fazer-se acompanhar por este aviso.

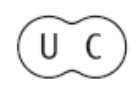





\title{
Entre a Tradição e a Inovação A agricultura da Beira Alta nos séculos XVIII e XIX
}

\author{
JoÃo Nunes DE OLIVEIRA \\ Faculdade de Economia \\ Centro de História da Sociedade e da Cultura da Universidade de Coimbra \\ jolivex@gmail.com
}

\section{Resumo:}

O presente trabalho trata da realidade agrícola da denominada Beira Alta (actuais distritos da Guarda e de Viseu) ao longo dos séculos XVIII e XIX. Debruçar-nos-emos sobre o seu património agrário, bem como sobre as mudanças e inovações que se foram sucedendo e seus reflexos sobre a economia do mundo rural.

Dedicaremos uma especial atenção ao aumento da mercantilização de alguns produtos, que se tornaram responsáveis pelo desenvolvimento de uma economia de mercado, situação que se tornou incentivadora de novos arroteamentos e do aumento de algumas produções, particularmente das mais rentáveis.

\section{Palavras chave:}

Província da Beira Alta, séculos XVIII e XIX, produções agrícolas, economia de mercado, mudanças e inovações.

\section{Abstract:}

This work deals with the agriculture reality of called Beira Alta (present districts of Guarda and Viseu), over the XVIII and XIX centuries. We will look over its agricultural heritage as well as on changes and innovation that have been happening and its impact on the economy of rural areas.

It will be paid closer attention to the increasing commercialization of some products, which became responsible for developing a market economy, a situation that has become a new supporter of ground clearance and the rise in some productions, particularly of the most profitable.

Keywords:

Beira Alta province, XVIII and XIX centuries, agricultural production, market economy, changes and innovations. 
«... a Beira, terra muito fertil de centeio, milho, castanhas, vinho, gados, caças e gostosos peixes, produzindo a amenidade deste país toda a diversidade de saborosíssimas frutas, especialmente os celebrados verdeais de Inverno...»

João Bautista de Castro

\section{Introdução}

É este um estudo que tem como principal objectivo fazer uma caracterização da realidade agrícola da denominada Beira Alta (que abrange aproximadamente os actuais distritos de Viseu e da Guarda) no decurso dos séculos XVIII e XIX. Procuraremos identificar o seu património agrário, acompanhando não só as mudanças e as novidades que entretanto se foram registando, mas também os cultivos que se mantiveram estáveis e que foram resistindo à inovação, bem como a acção polarizadora associada a algumas produções.

O período que aqui nos ocupa foi um tempo de mudanças, quer a nível nacional quer internacional. Em alguns países europeus foram-se mesmo registando alterações profundas a nível do mundo rural e da vida campesina, ligadas à comummente designada "revolução" agrícola. Mas nada de semelhante aconteceu em Portugal.

No entanto, o nosso País foi conhecendo, no século XIX, a ciência que se fazia no estrangeiro e foi importando algumas das grandes descobertas tecnológicas que então surgiram no mundo. A bibliografia sobre agronomia cresceu muito. A publicação de compêndios, tratados, guias, manuais, publicações periódicas é numerosa, tratando de uma pluralidade de temas, que tinham como finalidade aperfeiçoar a qualidade das plantas e dos animais, de modo a conseguir uma melhor e mais rendosa produção. O sistema de adubação, as técnicas de protecção das plantas, os novos instrumentos e a mecanização agrícola, o melhoramento no aproveitamento da água são temas também tratados, sempre com a intenção de poder contribuir para o progresso da agricultura. ${ }^{1}$ A pluralidade das inovações e mudanças registadas deu-se, no entanto, de uma forma lenta e desigual. As culturas e as práticas de cultivo tradicionais coexistiram com as novidades. Registou-se «uma discreta desordem», para utilizar a expressão do Visconde de Vilarinho de S. Romão.

Apesar de tudo, a nossa agricultura manteve-se muito arcaica e com baixos índices de produtividade.

1 Maria Carlos Radich, Agronomia no Portugal Oitocentista. Uma Discreta Desordem, Lisboa, Celta ed., 1996. 
Estamos em presença de um sector que desempenhava um papel primordial e mesmo dominante ${ }^{2}$, sendo a principal fonte de subsistência e responsável pelo desenvolvimento de outras actividades económicas. A agricultura era omnipresente e o trabalho da terra mandava e comandava toda a vida das populações.

A denominada Beira Alta situa-se no centro do País, abrangendo cerca de $10515 \mathrm{~km}^{2}$ e o seu território é constituído por terras de montanha, de colina e planícies, mas também encontramos vales estreitos apertados entre montanhas. Espaço de múltiplos cultivos e de variado revestimento vegetal, constituía uma miscelânea promíscua de muitas e variadas espécies; heterogéneo quanto à realidade geo-morfológica, climática, hidrológica e mesmo demográfica, condicionantes básicas do aproveitamento, utilização e organização do espaço e da distribuição das culturas.

Encontram-se nele diversos tipos de paisagens agrárias, reflectindo umas a influência atlântica e outras a influência continental. Mas surgem-nos também espaços onde há particularidades mediterrânicas, influenciando, por isso, o tipo e a variedade de culturas.

É um território com uma fisionomia polimórfica, constituída por um vasto planalto rodeado de montanhas de constituição predominantemente granítica, salpicada, por vezes, por emergências xistosas. Montanhas que interferem nas condições climatéricas, privando algumas das suas zonas das influências benéficas do Oceano Atlântico e acentuando a sua secura e aridez.

Trata-se, pois, de uma província com vincados contrastes.

Quanto aos cursos de água, encontramo-los em grande número e variedade, mas com caudais muito inconstantes. O aproveitamento da sua água, bem essencial à produção, é uma constante, existindo muitas presas, açudes e levadas de que se servem os lavradores para regarem os campos e criarem os seus frutos. ${ }^{3}$ Mas estes factores também se tornam responsáveis pelas desigualdades espaciais no que se refere ao processo de inovação e de modernização. Esta foi, de facto, fazendo o seu caminho, mas de um modo assimétrico e muito

2 Neste espaço a população activa ligada à agricultura em 1890 era bastante superior à média nacional. Ver António Rafael Amaro, Economia e Desenvolvimento na Beira Alta, Lisboa, Universidade Católica Ed., 2006, pp. 13-15.

3 Assim o diz, por exemplo, o pároco da freguesia de Cambra (termo de Lafões) em 1758, ao escrever na sua memória, que existem «... muitas levadas, prezas, e açudes de que se valem os habitadores deste citio para limarem, regarem, e fortalecerem os seus campos, com a qual agoa se criam os mantimentos...», in Instituto Arquivos Nacionais/Torre do Tombo (Lisboa), Memórias Paroquiais, vol. 8, mem. 59. 
lento, beneficiando de algumas benfeitorias e da aceitação de novas produções, e ainda da expansão de outras mais rentáveis.

Espaço onde é notória a acção humana, potenciadora da sua aptidão natural.

Sublinhe-se que o território que aqui analisamos está longe de ser homogéneo. Formado por uma diversidade geográfica bastante contrastante, com reflexos evidentes ao nível das próprias produções e mesmo do próprio povoamento ${ }^{4}$, nele se podem assinalar duas sub-regiões, bem distintas pela altitude, pelo clima, pelo revestimento vegetal e pelos modos de viver, cuja linha divisória poderá coincidir com o meridiano que passa aproximadamente por Tabuaço, Sernancelhe, Aguiar da Beira, Fornos de Algodres e Manteigas. Uma apresenta-se verdejante, mais húmida, mais produtiva, mais acolhedora e mais povoada - a parte mais ocidental - enquanto a outra é tendencialmente seca, mais pobre, agreste, pouco povoada e onde domina a rotina agrária, alternando o centeio com o pousio - é a parte oriental, também denominada Beira raiana. Esta é marcada pela interioridade geográfica e por maiores dificuldades de acesso aos mercados.

A diversidade geo-morfológica e climática existente no nosso espaço presta-se às mais diversas ocupações. Para além das terras amanhadas com diversas culturas, que coabitam frequentemente, encontramos também espaços ocupados por várias espécies arbóreas, sendo dignos de nota os pinhais, os carvalhais e os soutos. Mas nesta nossa paisagem rural destacam-se ainda os incultos, que atingem uma extensão significativa ${ }^{5}$. No entanto, tais incultos não estavam "à parte" da economia agrícola, servindo-se deles as populações para diversos fins.

Encontramos uma actividade agrícola diversificada onde a omnipresença dos cereais é uma evidência, destacando-se entre eles o cultivo do milho grosso (maís) e do centeio. O trigo, a cevada e a aveia também aparecem, mas em menor quantidade.

No entanto, o património agrícola não se fica por aqui, distribuindo-se por um leque muito variado de sectores. Assim, logo depois das culturas arvenses seguem-se a videira, a oliveira e as árvores de fruto - as culturas ricas - que

${ }^{4}$ Quanto ao povoamento, o nosso espaço tinha, por exemplo, em 1864 uma densidade demográfica superior - 56 habitantes por $\mathrm{km}^{2}$ - à que se registava a nível nacional - 44,4. No entanto, essa densidade não era aí homogénea, dado que o distrito de Viseu registava 72,9 habs $/ \mathrm{km}^{2}$ e o da Guarda apenas 39. In: X Recenseamento Geral da População, Tomo I, Vol. $1^{\circ}, 1960$, pp. 108 e 111.

5 Segundo Vitorino Magalhães Godinho, em pleno século XIX permanecem grandes extensões de terra por desbravar e por aproveitar. Ver "Reflexão Sobre Portugal e os Portugueses na sua História", in: Revista de História Económica e Social, Vol. 10, 1982, p. 10. 
se encontram disseminadas um pouco por toda a parte, destinando-se uma parte da sua produção a satisfazer a procura externa e a dinamizar a economia de mercado. Mas cabe ainda uma referência a outras produções - tidas como secundárias - que, apesar de terem uma expressão mais restrita, se tornam num complemento importante na magra dieta alimentar dos camponeses o feijão, o grão-de-bico, as lentilhas, as favas ou os produtos hortícolas, entre outros ${ }^{6}$. E duas novas culturas começavam então a dar os "primeiros passos": a batata e o arroz ${ }^{7}$.

O panorama existente era o de uma agricultura assente na policultura, cuja produção estava destinada primordialmente ao autoconsumo e onde a produção cerealífera se apresentava fortemente dominante, particularmente a do centeio e a do milho ${ }^{8}$, que eram a base do sustento das populações. Era uma agricultura muito marcada pela rotina e pela tradição, mas onde era perceptível o avanço das inovações, assim como dos sectores que se iam integrando paulatinamente na economia de mercado. Para uma melhor compreensão deste processo evolutivo do mundo rural deverá ter-se em conta a existência de um conjunto de factores que interferem com a agricultura, condicionando o seu potencial produtivo: os edafo-climáticos, as condições jurídico-institucionais e sociais, as solicitações do mercado, os condicionalismos técnicos, a componente humana, a dimensão das unidades de produção, as acessibilidades, etc.

Quanto à distribuição e inovação do património agrário, este não se caracteriza pela homogeneidade. Apresenta diferenças assinaláveis a nível da geografia produtiva, bem como quanto ao crescimento e desenvolvimento. A parte ocidental da nossa área (que corresponderá aproximadamente ao distrito de Viseu) e a parte oriental (a Beira raiana, que corresponderá aproximadamente ao distrito da Guarda) apresentam-se-nos com percursos diferenciados. A primeira apresenta um maior dinamismo, variedade e prosperidade: é onde os processos de modernização são uma realidade objectiva, que se estende a vários sectores. A segunda é mais atrasada. Aqui as estruturas produtivas tradicionais persistem: as permanências sobrepuseram-se às mudanças, e os

6 Realidade que se constata através da leitura das Memórias Paroquiais. Ver também o que dizem sobre isto: António Rafael Amaro, Economia..., cit., pp. 197-202 e João Nunes de Oliveira, A Beira Alta de 1700 a 1840. Gentes e Subsistências, Viseu, Palimage Ed., 2002, pp. 104-107 e 121-122.

7 As únicas notícias que encontrámos sobre o cultivo de arroz são respeitantes à recolha do dízimo nos anos de 1783/84 e de 1785/86, na localidade de Prime, próximo da cidade de Viseu.

8 Em 1882-1883, o milho representava 46,2\% do total da produção dos três cereais, seguido de perto pelo centeio, com 44\%, e por último o trigo, com apenas 9,8\%. Ver António Rafael Amaro, Economia..., cit., p. 167. 
cultivos mantiveram-se mais estáveis. O centeio, por exemplo, continuou dominante e o maís quase não se implantou: precisamente o contrário do que aconteceu na outra sub-região.

Mas um outro espaço se destaca, merecendo uma atenção especial. É a área norte-beirã, confinante com o rio Douro, onde se assiste a uma grande mudança e inovação, registando-se uma progressão cada vez maior na especialização da viticultura, impulsionada, no decorrer do século XVIII, pelo crescimento da procura e pelo elevado preço que a pipa de vinho atingiu. Processo de especialização esse que se consolida e intensifica no século XIX. Estamos em presença de um produto bem remunerador, dada a sua vocação exportadora, que estimula a ampliação da área plantada de videira, em detrimento de outras culturas menos rentáveis. E esse espaço foi-se metamorfoseando e integrando numa agricultura capitalista, dada a grande procura que o vinho tinha no mercado externo - o nacional e o internacional.

Neste cenário agrícola merecem-nos uma atenção particular o maís, a videira e a batata, com destaque para as duas primeiras ${ }^{9}$. Tornaram-se uma mais valia de grande importância, tendo sido responsáveis por mudanças significativas a diversos níveis, revelando uma dinâmica que não se pode comparar com qualquer das outras produções aqui existentes.

\section{A cerealicultura}

O estudo realizado permite-nos constatar que, enquanto algumas culturas se mantiveram ao longo dos tempos, outras foram perdendo importância até desaparecerem, cedendo o seu espaço a outras que foram surgindo. Assim aconteceu particularmente com o painço e o milho miúdo, que viram reduzidos os seus valores produtivos até praticamente desaparecerem da nossa documentação. Mas neste processo inovador que acompanha os séculos XVIII e XIX, também o centeio vai perdendo espaço e importância. E a responsabilidade por tais comportamentos coube ao aparecimento e expansão do milho grosso (maís), planta milagrosa, assim denominada por Fernand Braudel ${ }^{10}$, a qual se irá transformar na grande responsável pelas múltiplas alterações que então se virão a registar no nosso mundo rural.

9 O vinho e o milho eram considerados, pelo periódico «O Comércio de Viseu» de 5 de Agosto de 1886, os únicos géneros que o proprietário da Beira Alta dispunha para vender. Acrescentando que era quase exclusivamente destes dois produtos que ele tirava todo o seu rendimento com que satisfazia as despesas da vida. Ver António Rafael Amaro, Economia ..., cit., p. 207.

${ }^{10}$ Fernand Braudel, Civilização Material e Capitalismo, nos séculos XV-XVIII. As Estruturas do Quotidiano, Tomo I, Lisboa, Teorema ed., 1992, p. 136. 
Quanto ao maís (de procedência ameríndia) alargou e acentuou a sua posição na economia cerealífera da nossa região, registando um aumento significativo da produção ${ }^{11}$. Passou a mobilizar e a assumir um papel cada vez mais relevante, tendo acentuado a sua posição como cultura principal entre os cereais panificáveis. A sua expansão não se processou, no entanto, de um modo uniforme: há que ter em conta as condições naturais, mas também as económicas e sociais. É na parte ocidental (distrito de Viseu) que encontra a condições edafológicas mais favoráveis ao seu rápido desenvolvimento, tendo-se tornado claramente dominante ${ }^{12}$.

$\mathrm{O}$ maís viria a adquirir um protagonismo capital. Importante para o consumo humano, é-o também para a alimentação animal, podendo mesmo dizer-se que tudo nele é susceptível de ser aproveitado. Os seus altos, ou mesmo altíssimos, rendimentos provocaram a sua ampla e rápida difusão, convencendo os agricultores dos benefícios que poderiam auferir. Acolhimento que teria ficado a dever-se a algumas peculiaridades incontestáveis, destacando-se entre elas a elevada produtividade, que se distanciava claramente da dos outros cereais ${ }^{13}$, a fácil co-habitação com outras culturas, particularmente o feijão, a abundância de alimento para os animais, através do aproveitamento de vários dos seus subprodutos e a ocupação da terra por menos tempo. É que se está em presença de uma planta com um curto ciclo vegetativo, mediando pelos quatro meses, enquanto o centeio e o trigo precisam de seis a oito. Situação esta que possibilita uma segunda sementeira com outro renovo.

O maís iria ser responsável por uma "revolução" agrária, que no início não se previa. De uma curiosidade botânica a alimento destinado ao gado, tornar-se-ia o alimento e a salvação das pessoas pobres. E a partir do século XVIII vê-lo-íamos tornar-se um consumo de larga escala e um autêntico alimento popular ${ }^{14}$.

Como cultura mais compensadora, vai registando um lento mas incessante processo de difusão, conduzindo a uma mudança no mapa cerealífero da nossa região. Expansão que se fez principalmente à custa dos outros dois milhos

${ }^{11} \mathrm{O}$ milho grosso, segundo Gauro Coppola, era um tipo de produção que estava estruturalmente apoiada na «petite culture», que requeria limitados investimentos mas que necessitava de uma forte componente de trabalho humano. In: Il Mais nell'Economia Agrícola Lombarda (dal secolo XVII all'Unitá), Bologna, Il Mulino, 1979, p. 136.

${ }^{12}$ Ver João Nunes de Oliveira, A Beira Alta..., cit., pp. 65-85 e António Rafael Amaro, Economia..., cit., pp. 166-180.

${ }^{13} \mathrm{O}$ milho grosso atinge altos rendimentos - 32 grãos por cada semeado - enquanto o trigo, em solos melhores e em anos de boa produção só chega a 7 ou 8 grãos, porque o normal eram 3 ou 4.

${ }^{14}$ Orlando Ribeiro, Portugal o Mediterrâneo e o Atlântico, Lisboa, Sá da Costa Ed., 4 a ed., 1986, pp. 115-122. 
- o painço e o milho miúdo - e também do centeio, que viram reduzido o seu espaço vital, "disputado" pelo novo renovo.

É incontestável que o século XVIII marca a vitória do maís na área que hoje corresponde ao distrito de Viseu. Logo em 1700/1701 ele nos aparece a tomar a dianteira, afirmando-se cada vez mais com o decorrer dos anos, particularmente a partir de 1720/1721 ${ }^{15}$.

A progressiva aceitação e expansão desta nova espécie (maís) contribuiu para acentuar a redução do milho miúdo e do painço, que foram vendo reduzida, progressiva e significativamente, a sua expressão, sendo gradualmente desapossados do seu espaço vital e finalmente expulsos, aparecendo-nos apenas de quando em vez com valores reduzidíssimos e enquistados em reduzidos, pobres e isolados espaços.

Neste seu percurso vitorioso, a posição de destaque desempenhada pelo centeio, ao longo dos tempos, no sistema alimentar das populações da nossa região, vai ser ameaçada e relegada para uma posição mais modesta, mas sem atingir a reduzida dimensão dos outros dois cereais acima mencionados.

A disputa pela obtenção de espaço vital que se foi travando entre o maís e o centeio, por um lado, e entre o maís e os outros milhos (o painço e o miúdo) por outro, é prolongada, lenta, mas progressivamente favorável. Disputa que é detectável no decurso do século XVII. Neste século os milhos (painço, miúdo e grosso) vão-se afirmando e os seus valores produtivos no monte dos cereais vão-se aproximando dos do centeio. E a partir de 1683 a supremacia dos milhos é já notória e a sua distância em relação ao centeio vai-se alargando. Supremacia que ficava já a dever-se ao maior protagonismo e dinâmica do maís ${ }^{16}$.

A partir do início do século XVIII a supremacia dos milhos sobre o centeio é por vezes bem expressiva. Em 1718/1719 entramos definitivamente no "reinado" dos milhos, os quais não mais deixarão de ver aumentada a sua vantagem.

Até $1708 / 1709$ as três espécies de milho fazem parte do registo do dízimo recolhido. No entanto, nesta data passam apenas a ser registados o graúdo e o miúdo, deixando o painço de nos aparecer nessa documentação. E a partir de então a luta dentro da família dos milhos desenrolou-se entre o miúdo e o graúdo, tendo este atingido em 1740/1741 um valor bem expressivo, quando se torna responsável por $79,1 \%$ da produção total dos milhos.

Da década de oitenta (do mesmo século) em diante, acentua-se ainda mais a supremacia do maís sobre o milho miúdo e também sobre o centeio, tendo-se

15 João Nunes de Oliveira, A Beira Alta ..., cit., pp. 61-85.

${ }^{16}$ João Nunes de Oliveira, A Produção Agrícola de Viseu entre 1550 e 1700, Viseu, ed. Câmara Municipal de Viseu, 1990,pp. 28-47. 
o quantitativo do milho miúdo tornado praticamente residual no decurso da década de noventa.

Apesar de ter sido no século XVIII que o milho grosso mais se expandiu, no século XIX ele continua a sua caminhada, apesar de o fazer de um modo mais lento. Através da figura 1, que se segue, ficamos a conhecer essa realidade cerealífera.
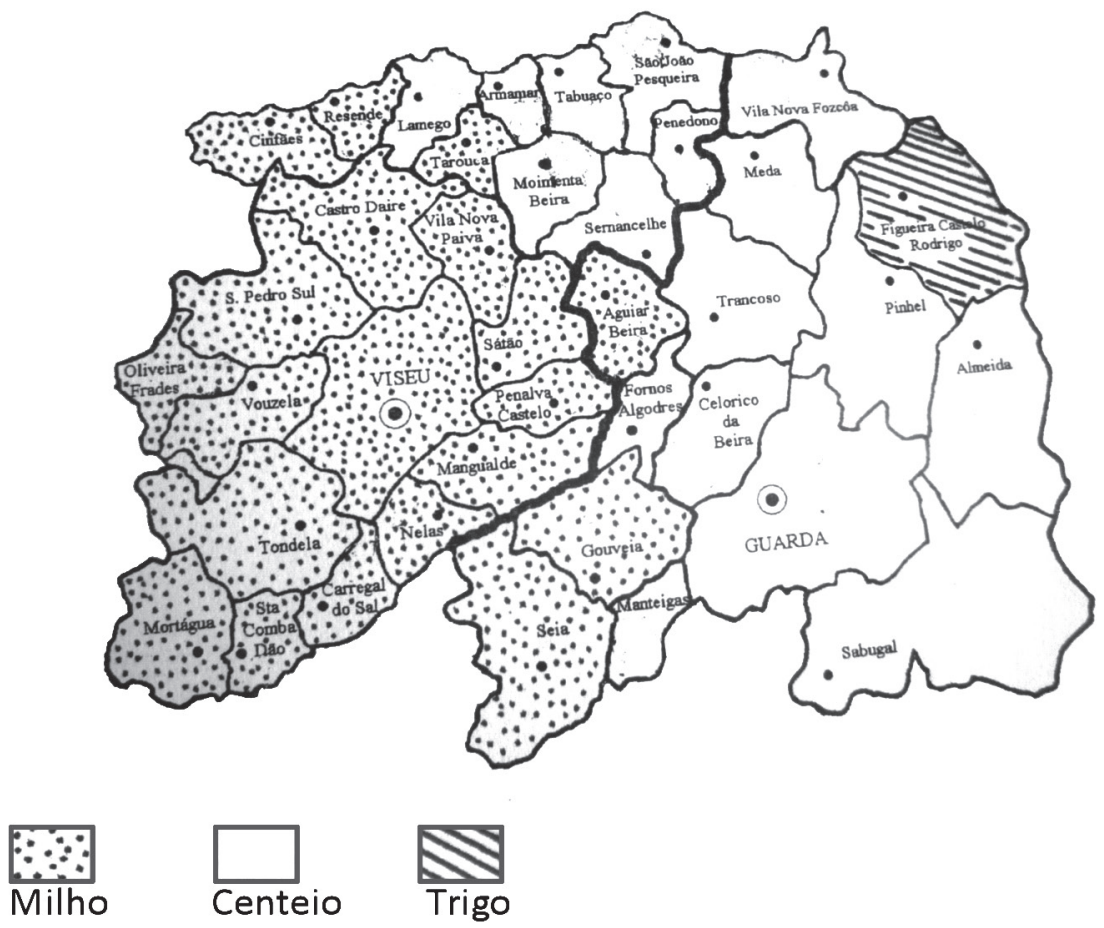

Figura 1 - Predomínio cerealifero por concelho, em 1901

No actual distrito de Viseu, dos 24 concelhos que o constituem, em 17 (71\%) domina o maís e apenas em 7 (29\%) domina o centeio. E no actual distrito da Guarda, dos 14 concelhos que o constituem, em 10 (71\%) domina o centeio, em $3(21 \%)$ o maís e em apenas um (8\%) aparece-nos em primeiro lugar o trigo. E é de notar que os três concelhos dominados pelo maís (Aguiar da Beira, Gouveia e Seia) são limítrofes do distrito de Viseu ${ }^{17}$.

${ }^{17}$ António Rafael Amaro, Economia..., cit., pp. 177-180. 
Mas o maís não se acomodou a este domínio, tendo continuado a conquistar espaço e tendo passado a ocupar, em 1940, o primeiro lugar nos concelhos de Armamar, Lamego, Moimenta da Beira, Penedono e Sernancelhe, todos eles pertencentes ao distrito de Viseu.

A sua expansão implicou a introdução de melhorias nos factores de produção, como seja ter obrigado o homem a recorrer à captação e exploração de água e consequente alargamento da rede de irrigação, já que a água era imprescindível ao seu desenvolvimento e produtividade. Mas o seu cultivo mexeu também com a própria morfologia de alguns terrenos, construindo-se socalcos nos terrenos inclinados de modo a aproveitar o mais convenientemente possível a rega.

Das novas e variadas sementes trazidas do continente americano, o maior destaque recairá com certeza no maís, pelas alterações que provocou e pelo efeito "revolucionário" que teve no sistema agrário dominante, tendo mesmo a sua expansão provocado entre muitas outras mudanças, já mencionadas, a diminuição do alqueive, assim como a promoção de um novo sistema de alternância de culturas, o que permitiu, como cultura de Primavera que é, uma distribuição mais racional dos trabalhos agrícolas. Contribuiu ainda para a expansão do prado, proporcionando um aumento da criação de gado e consequente aumento da produção de estrume, que viria a contribuir para uma melhor fertilização do solo, reflectindo-se nos índices de produtividade.

\section{A Batata}

Um outro produto tributário da expansão é a batata. Estamos em presença de outra cultura "revolucionária", mas que apenas terá iniciado a sua expansão ao longo do século XVIII. Faz então uma tímida aparição e vai atingindo cada vez mais projecção no decurso do século XIX. A sua difusão processou-se de uma forma bem mais lenta do que o maís, exigindo mais tempo para se afirmar. Muito teve que fazer para vencer resistências e receios. Ir-se-á tornar, apesar de tudo, um importante sucedâneo dos cereais, aumentando por isso a diversificação das colheitas. Mais um produto que se acrescenta à dieta alimentar, contribuindo para minimizar as frequentes carências cerealíferas. No entanto, a democratização do seu consumo acentuar-se-á nos finais do século XIX, vindo a tornar-se no "salvatério" da alimentação de todos apenas no século $\mathrm{XX}^{18}$.

${ }^{18}$ António Rafael Amaro, Economia... cit., pp. 182-191; M. Margarida Sobral Neto, "Introdução e Expansão da Cultura da Batata na Região de Coimbra (séculos XVII-XIX)", 
Renovo com altos índices de produtividade, dá-se bem em terras altas (pode subir até aos 1400 metros de altitude), leves, enxutas e permeáveis, como eram os solos de origem granítica, tendo-se processado a sua expansão, inicialmente, à custa do trigo e do centeio. À semelhança do maís tem um ciclo vegetativo curto - anda à volta dos quatro meses - e como tal permite um maior uso dos solos, podendo interferir no afolhamento, suprimindo uma das folhas de repouso.

A primeira referência à "castanha da Índia", que pensamos tratar-se do referido tubérculo ameríndio, encontramo-la em 1705 num registo de compras feito pelo Seminário de Viseu ${ }^{19}$. Quanto ao seu cultivo, só iremos ter notícias dele em 1758, nas Memórias Paroquiais, mas apenas em três localidades do concelho de Penedono (Granja, Penedono e Póvoa de Penela) ${ }^{20}$. Pensamos que estas escassas notícias não reflectirão a sua verdadeira realidade. $\mathrm{O}$ seu cultivo seria já então mais extenso, cultivo que teria sido impulsionado a partir de 1762, devido às dificuldades cerealíferas criadas pelos estragos da guerra que então se desenrolou. E nestas situações de escassez e de preços elevados o camponês lança mão de todos os meios com vista a aumentar os parcos recursos alimentares, sendo, pois, ultrapassados alguns preconceitos, como então aconteceria com a batata. As duras necessidades obrigaram o homem a tolerar que ela passasse a fazer parte, mais frequentemente, da sua dieta alimentar ${ }^{21}$.

Novo impulso, e este decisivo, vamos tê-lo no princípio do século XIX, promovido pelas determinações e incentivos das autoridades de Lisboa, no contexto das dificuldades de abastecimento provocadas pelas Invasões Francesas (1807-1811).

Tempos de fome e de grandes e constantes subidas dos preços dos cereais, que atingem valores elevadíssimos e preocupantes, dada a sua grande escassez! É neste contexto que as autoridades de Lisboa ordenaramm às autoridades

in Revista Portuguesa de História, Tomo XXIX, 1994, pp. 55-77 e Maria Carlos Radich, Agronomia... cit, pp. 54-57.

19 Arquivo Distrital de Viseu - Livro de Contas do Seminário de Viseu, Livros 7/386, 10/390, 14/392, 15/393, 18/387, 21/396, 22/397 e 23/747.

${ }^{20}$ Instituto Arquivos Nacionais/Torre do Tombo (Lisboa), Memórias Paroquiais, Vol. 17, mem. 102; Vol. 28, mem. 114; Vol. 30, mem. 245.

${ }^{21}$ João M. de Campos e Mesquita, "Extracto da Memória sobre o Destroço das Criações de Gado Vacum; Apresentada à Academia”, in: Memórias da Academia Real das Ciências de Lisboa, 1789-1815, Tomo IV, Lisboa, Ed. Banco de Portugal, 1991, pp. 316-317; David Justino, A Formação do Espaço Económico Nacional. Portugal 1810-1913, Vol. I, Lisboa, Vega, 1988, p. 41; B. H. Slicher Van Bath, História Agrária da Europa Ocidental (500-1850), Lisboa, Editorial Presença, 1984, pp. 266-267. Ver também Michel Morineau, “ La Pomme de Terre au XVIII siècle”, in Annales, Novembre/Décembre, 1970, pp. 1767-1785. 
locais, como, por exemplo, aos Corregedores de Lamego e de Trancoso, que obriguem os agricultores a semear batata, porque "não só façelita huma produção certa mas tambem subministra hum alimento saudavel e é huma cultura que segura milhor que nenhuma outra a subsistencia dos Povos" ${ }^{22}$. Ordens que eram acompanhadas de ameaças, com penas variadas para os agricultores que não acatassem tais determinações. E os apoios concedidos pela Grã-Bretanha, no pós invasões francesas, para restabelecer a agricultura arruinada da nossa região, contemplavam também semente de batata, entre muitas outras.

No final da primeira metade do século XIX a Beira encontrava-se no grupo das províncias que em Portugal lideravam a produção desse tubérculo. De acordo com David Justino, no quinquénio de 1848-1852 mais de 2/3 da produção portuguesa de batata tinha origem nos quatro distritos que constituíam as províncias de Trás-os-Montes e da Beira Alta ${ }^{23}$. E no início do último quartel do século XIX (1874-1877) a Guarda era o distrito onde a sua produção estava mais divulgada, respondendo por $70 \%$ da batata produzida na Beira Alta, com 26167 toneladas, sendo o distrito de Viseu responsável por 11297 toneladas. No entanto, a sua produção intensifica-se neste último quartel do século XIX, particularmente de um modo mais notório no distrito de Viseu: avanços que passam pela ocupação dos melhores terrenos, deixando de confinar-se às terras altas, como aconteceu nos primeiros tempos.

Que as condições geo-climáticas eram adequadas ao seu desenvolvimento prova-o a sua quota de produção, tendo atingido a nossa área (11,6\% do território nacional) 31,2\% do total nacional, no início do século XX (1901-1904)24. $E$, à medida que o seu cultivo se vai expandindo, o seu consumo a nível familiar vai também crescendo, tornando-se assim uma fonte de receita para o agricultor, aumentando o seu peso no produto agrícola regional.

\section{As hortícolas e as leguminosas}

No contexto de uma agricultura de Antigo Regime, não será descabido referir ainda toda uma vasta gama de outros produtos de que o homem de

${ }^{22}$ Arquivo Histórico da Câmara Municipal de Lamego - Livro que hade servir para os Actos de Camara desta cidade de Lamego, 1805 a 1808, fl. 82v. e 83 e Livro que hade servir somente para o Registo das Ordens da Intendencia Geral da Policia da Corte e Reino que vierem a registar à Camara desta Cidade de Lamego, 1798/1813, fl. 146.

${ }^{23}$ David Justino, A Formação..., cit., p. 42.

${ }^{24}$ Vitorino Magalhães Godinho, "Reflexão Sobre Portugal e os Portugueses na sua História", in Revista de História Económica e Social, n 10, 1982, p. 10; António Rafael Amaro, Economia... cit., pp. 185-186. 
então podia lançar mão, particularmente em tempos de carências cerealíferas. Referimo-nos aos produtos hortícolas e às leguminosas. Quanto aos primeiros fomo-los encontrando espalhados pela nossa região. A sua variedade é grande, como mostram os «Livros de receitas e despesas» de algumas instituições ou então a listagem apresentada pelo pároco da freguesia de Germil (freguesia de Penalva do Castelo), em 1758, ao afirmar:« As ervas que há são as seguintes: couves, alfaces, chicórias, celgas, borragens, espinafres, e alguns repolhos... também se planta nas hortas para tempero da cozinha ortelã, salsa, segurilha» ${ }^{25}$.

Estamos perante uma produção que se caracteriza pela estreita conexão entre autoconsumo e comercialização, já que as hortas tinham uma expressão mais significativa na paisagem rural periurbana e intra-urbana, inserindo-se na economia de mercado dinamizada pelos centros urbanos e melhoravam substancialmente os ganhos dos seus cultivadores. Realidade esta que sobressai da leitura do que afirmam, por exemplo, os párocos de Almeida, Trancoso e Viseu, em 1758, nas suas memórias. Um dos párocos desta última cidade diz que há “... munta e notavel ortaliça... de que se abastece huma grande parte da cidade", e o de Trancoso escreve “... dos lugares vizinhos vem todos os dias à praça hortaliças" ${ }^{26}$.

Mas o interessante é que o facto de este ser um cultivo de quintal ou de «jardim», que requer muitos cuidados, vai transformar esses mesmos «jardins» em verdadeiros viveiros experimentais de novas plantas, como aconteceu, por exemplo, com o milho grosso e a batata.

Quanto à produção de leguminosas - feijão, grão-de-bico, lentilhas, favas, tremoços, etc. - fomo-la também encontrando espalhada pelo nosso espaço, com particular destaque para o feijão. Tais produtos asseguravam e acrescentavam a disponibilidade alimentar do camponês e sua família. E para além de alimento do homem e de animais, as leguminosas tinham também propriedades nitrificantes, tornando-se úteis à reconstituição dos solos, por serem ricas em azoto.

\section{Viticultura, oleicultura e fruticultura}

Outra actividade produtiva de grande importância e que desempenha um papel chave na economia beirã é a vitivinicultura. Este sector acabaria

${ }^{25}$ Instituto Arquivos Nacionais/Torre do Tombo (Lisboa), Memórias Paroquiais, vol. 17, mem. 39 .

${ }^{26}$ João Marinho dos Santos, Notícias e Memórias Paroquiais Setecentistas - 4 Almeida, Viseu, Palimage ed., 2005, p. 53; Memórias Paroquiais, vol. 43, mem. 450, fl. 411; João Nunes de Oliveira, Notícias e Memórias Paroquiais Setecentistas - 1 Viseu, Viseu, Palimage ed., 2005, pp. 202 e 207. 
por fazer a diferença, tendo tido um papel dinâmico e de arrastamento da agricultura da região, fugindo ao padrão agrícola familiar e de pura subsistência. Com um elevado grau de mercantilização, torna-se responsável por uma maior monetarização da actividade agrícola, tendo contribuído para uma redução da policultura e do "autoconsumo", sendo, por isso, fortemente responsável pelo desenvolvimento de um processo de modernização da agricultura. Estamos, pois, em presença de "um produto estratégico e vantajoso", no dizer de Aurélio de Oliveira. Os vinhos tornar-se-iam um sector rentável e de um crescente interesse económico, quer para particulares, quer ainda para os Municípios e também para o poder $\mathrm{Central}^{27}$.

Para além da produção de vinho, o grande responsável pelo sucesso comercial deste sector, temos também de ter em conta a produção de aguardente e de vinagre, produtos que fomos encontrando e que proporcionavam rendimentos apreciáveis.

A videira marca presença em praticamente toda a nossa região, adaptando-se bem a terrenos pouco aptos a outras culturas, tais como encostas declivosas e fragosas. Presença que Duarte Nunez de Leão, entre outros autores, sublinha na sua obra, afirmando que os vinhos na Beira eram muitos ${ }^{28}$. E que assim era de facto, deduz-se da leitura das «Memórias Paroquiais», onde fomos encontrando referências em praticamente todas as freguesias. Fomo-nos também deparando com uma diversidade qualitativa que podia adequar-se a diferentes padrões de consumo.

Para além dos vinhos referenciados com o epíteto de "selecto" ou de "excepcional", como acontece, por exemplo, em Santa Leocádia (Tabuaço), em Cambres (Lamego), ou em Silgueiros (Viseu), entre outras localidades, produzem-se também vinhos comuns de muitas espécies e que são fundamentalmente destinados ao auto-consumo e ao consumo local.

No nosso espaço coexistem duas grandes categorias de vinhos - os maduros e os verdes - sendo estes produzidos nas terras baixas, húmidas e pouco soalheiras. A produção dos maduros suplanta a dos verdes. Em meados do

${ }^{27}$ Aurélio de Oliveira, "Os Vinhos em Portugal (1300-1820). Um Sector de Sucesso na Agricultura Bloqueada do Antigo Regime", In Douro - Estudos e Documentos, Porto, G.E.H.V.I.D., n ${ }^{\circ} 22,2007$, pp. 255-270.

${ }^{28}$ Duarte Nunez do Leão, Descripção do Reino de Portugal, Lisboa, Jorge Rodriguez, 1610, p. 41. Ver também João Nunes de Oliveira, "Algumas notas sobre a cultura da vinha e sobre o vinho na «Região do Dão», entre 1600 e 1832”, in: Douro - Estudos e Documentos, Vol. V (10), $2000\left(2^{\circ}\right)$, pp. 117-133. Segundo Armando de Castro, a Beira era, no ano de 1852, responsável por 31,3\% da produção total do nosso País. Ver "Vinho", in Dicionário de História de Portugal, Vol. IV. Porto, Iniciativas Editoriais/ Figueirinhas, 1971, pp. 315-321. 
século XIX (1852) os maduros eram responsáveis por 75,2\% do total produzido, enquanto aos verdes cabia apenas $24,8 \%{ }^{29}$. De um modo geral, os vinhos de qualidade destinavam-se também à exportação, mesmo para «Reinos estrangeiros», como acontecia com a generalidade dos vinhos produzidos no Douro e ainda com outros produzidos na região hoje denominada de região do Dão, beneficiando como tal das condições favoráveis de mercado ${ }^{30}$.

Nas nossas leituras fomo-nos deparando com espaços que se iam destacando pela boa ou mesmo excelente qualidade dos seus vinhos, sobressaindo entre estes os produzidos na margem esquerda do rio Douro. Mas também se produziam vinhos de qualidade em localidades à volta de Viseu, Tondela, Nelas, Mangualde, Penalva do Castelo e nas freguesias de Oliveira do Conde (Carregal do Sal) e de Pinhanços (Seia), espaços que hoje pertencem à denominada região do Dão, sendo mesmo muitos deles exportados para fora do Reino. E os vinhos produzidos na área de Pinhel e de Trancoso também não passam despercebidos, merecendo referências elogiosas. Já em 1609 Manoel Severim de Faria se refere aos vinhos de Trancoso como sendo abundantes e bons e em 1758 o pároco desta vila afirma que “...no q. mais se singulariza e excede às mais povoações de toda a Beira, hé na feitoria dos generozos vinhos q. recolhe" ${ }^{31}$. Assim, à medida que a viticultura foi crescendo e o tempo decorrendo, foram-se afirmando zonas como a do Dão, a de Trancoso e de Pinhel, e principalmente a do Douro.

São os vinhos produzidos no termo da cidade de Lamego, de Armamar, de S. João da Pesqueira, de Tabuaço e de Resende - os vinhos do Douro - que mais se destacam e dominam. Desde longa data que se lhes encontram as referências mais elogiosas, tornando-os objecto de uma forte mercantilização ${ }^{32}$.

${ }^{29}$ Armando de Castro, “Vinho”, in: Dicionário de História de Portugal, Vol. IV, pp. 315$-321$.

${ }^{30}$ A boa saída que o vinho tem devido ao comércio com os ingleses, leva a que “... todos cuidão muito na boa cultura e acrescentamento das vinhas...", como escreve o pároco de Tondela, em 1858. Instituto Arquivos Nacionais/Torre doTombo (Lisboa), Memórias Paroquiais, Vol.43, mem. 440 .

${ }^{31}$ Manoel Severim de Faria, Viagens em Portugal de Manuel Severim de Faria, 1604, 1609 e 1625. Compilação de Joaquim Veríssimo Serrão. Lisboa, Academia Portuguesa de História, 1974, p. 122; Instituto Arquivos Nacionais/Torre do Tombo (Lisboa), Memórias Paroquiais, Vol. 43, mem. 450.

${ }^{32}$ Por exemplo, Rui Fernandes, em 1532, diz na sua obra que nos terrenos em redor da cidade de Lamego se produzia abundante e excelente vinho, que se exportava e se levava para outros locais do Reino. In: Descripção do Terreno em Roda da Cidade de Lamego Duas Leguas, Lamego, Edição de Augusto Dias, 1947, pp. 21-23 e 29-30.

Sobre o desenvolvimento da viticultura em redor da cidade de Lamego, ver: João Nunes de Oliveira “ O Vinho do Douro na Região de Lamego entre 1700 e 1850”, In: Revista de História da Sociedade e da Cultura, n³, 2003, pp. 119-152 e também "O Vinho do Douro em Lamego 
Aproveitando as facilidades de escoamento proporcionadas pelo rio Douro, chegam à cidade do Porto e daqui embarcam para o estrangeiro, particularmente para a Grã-Bretanha. O êxito e crescimento das suas exportações vão-se acentuando progressivamente a partir do último terço do século XVII, devido à maior procura inglesa. $\mathrm{E}$ os fortes rendimentos proporcionados levam a uma paulatina substituição de culturas menos rentáveis pelas cepas "milagrosas". É assim que campos de pão ${ }^{33}$, terrenos de olival, encostas de soutos e até mesmo montes que apenas produziam matos vão sendo surribados e plantados de vinha. Vinha que se vai estendendo ao longo de íngremes arribas, obrigando o homem à correcção das imperfeições naturais do terreno através da construção de socalcos ou terraços, cintando-os com muros para plantar o bacelo. Está, pois, em curso o irreversível processo de transformação de uma área, com benefícios para toda a região.

Trata-se de uma produção com uma forte capacidade polarizadora, exercendo um domínio efectivo no espaço e cujo raio de acção ultrapassa os seus limites naturais, reflectindo-se nas áreas circundantes. Estas passam a fornecer mãode-obra e produtos agrícolas alimentares que o espaço por ela ocupado deixa de produzir.

A grande importância que a viticultura vai tendo, quer a nível regional quer mesmo a nível nacional, vai obrigar o poder político a uma progressiva intervenção, como aconteceu, por exemplo, com o vinho do Douro. Ao longo do período tratado assistimos à criação de mecanismos de fiscalização e controlo da produção e da circulação, de modo a proteger a qualidade e manter o prestígio e os mercados. Legislação disciplinadora que tem o seu início com Sebastião José de Carvalho e Melo, através do Alvará de 10 de Setembro de 1756, que institui a Companhia Geral de Agricultura das Vinhas do Alto Douro e que muita polémica iria provocar ao longo dos tempos ${ }^{34}$.

A procura cada vez maior e o preço compensador que o vinho do Douro atingia, tornar-se-iam num factor favorável ao paulatino, mas constante,

entre 1850 e 1932”, In: Revista de História Económica e Social, n 8-2a série, 2004, pp. 37-77; Aurélio de Oliveira, "Vinhos de Cima-Douro na primeira metade do século XVII", In Gaya, Vol. II, 1984, e também "Douro País Vinhateiro", In, Revista de História, Centro de História da Universidade do Porto, Vol. XII, 1993, pp. 221-243.

${ }^{33}$ Os próprios campos de pão não escaparam à expansão da videira no século XVIII, como se depreende dos lamentos da vereação da Câmara de Lamego, na sessão de 6 de Maio de 1801, ao queixar-se da muita falta de pão "por que nelle se cultiva muito pouco em rezão de huma grande parte das terras do mesmo termo serem propriedades de vinhas...". Arquivo Histórico Municipal de Lamego, Livro de Actas de 1797 a 1801, fl. 173.

${ }^{34}$ Conceição Andrade Martins, Memória do Vinho do Porto, Lisboa, I.C.S., 1990. 
alargamento das áreas de plantio de mais videiras, nos séculos XVIII e XIX. Expansão essa que é ainda mais facilitada com as medidas que vão sendo tomadas, entre 1788 e 1865, em relação aos privilégios que a Companhia detinha. Privilégios esses que foram sendo diminuídos até se chegar à sua revogação total quando ela foi extinta ${ }^{35}$.

Também a demolição do Cachão da Valeira, concluída em 1792, e que permite a navegabilidade do rio Douro até Barca de Alva, favorece a expansão vitícola nos espaços a montante do Cachão, cujos vinhos passam a competir mais facilmente com os da região demarcada. Daí que desde o primeiro quartel do século XIX grandes proprietários e negociantes invistam em extensas plantações de vinhedos e em compras de vinho no Douro Superior. No entanto, a valorização vitícola desse espaço só se tornaria decisiva na segunda metade do século.

Mas, para além de terem sido as áreas confinantes com o rio Douro, como Vila Nova de Foz Côa, Meda e Figueira de Castelo Rodrigo, que mais beneficiaram com as obras do Cachão da Valeira, também as comarcas de Trancoso e de Pinhel, no seu todo, sentiram os efeitos favoráveis que a expansão da navegabilidade do rio Douro proporcionou, ao facilitar o escoamento dos seus vinhos e de outras produções, até à cidade do Porto.

Nesta melhoria das acessibilidades, não podemos esquecer o impacte que o caminho de ferro trouxe para a evolução sócio-económica desta área. O comboio chega à Régua em 1879, ao Pinhão em 1880 e em 1887 a Barca d'Alva ${ }^{36}$.

${ }^{35} \mathrm{O}$ ataque aos privilégios da Companhia começou a verificar-se com a subida ao trono de D. Maria II, em 1777, adoptando uma política mais liberalizante, que leva ao alargamento da área demarcada, em 1788, o que provoca um maior dinamismo do sector. É, no entanto, entre 1821 e 1865 que se registam as maiores alterações e se viveu um dos períodos mais conturbados, como o confirmam as actas da vereação da Câmara da cidade de Lamego. Assim, a vitória do movimento liberal provoca também um cerceamento de alguns privilégios da Companhia, logo em 1821 e 1822. E em 30 de Maio de 1834 é extinta e proclama-se a liberdade para a produção e para a comercialização. Situação que favorece a expansão descontrolada da área de vinha cultivada. Mas em 1838 é restaurada, mas com poderes e competências muito mais limitados, que, no entanto, irão ser ampliados pela lei publicada em 21 de Abril de 1843 . Mas, dez anos depois, o decreto de 11 de Outubro de 1852 irá revogar os seus privilégios. E finalmente, pela Carta de Lei publicada em 7 de Dezembro de 1865 toda a legislação regulacionista é revogada, tendo a demarcação sido abolida e instituída a liberdade de produção e de comercialização. Ver Gaspar Martins Pereira, O Douro e o Vinho do Porto: de Pombal a João Franco, Porto, ed. Afrontamento, 1991.

${ }^{36}$ Maria Helena Mesquita Pina, "Alguns reflexos da implantação do caminho de ferro no Alto Douro no final do século XIX", in Revista da Faculdade de Letras - Geografia, I série, vol. XIX, Porto, 2003, pp. 397-419. 
A partir de 1865 inicia-se um novo período que se prolongará até 1907 - o período mais liberal na vida dos vinhos do Douro - em que se regista um aumento da concorrência e uma profunda reestruturação do espaço regional. Situação que irá desaguar numa grave crise nos finais do século XIX que obrigará, de novo, o poder central a intervir, em 1907, impondo um novo regime regulatório proteccionista ${ }^{37}$.

Aumento de produção que se regista também nas outras áreas vinhateiras ${ }^{38}$. No decurso do último terço deste século, particularmente a partir da superação da grave crise provocada pelos problemas fitossanitários - oídio, míldio e filoxera - que assolam a região beirã, assiste-se a um alargamento da área plantada. Crise que obrigou a um forte esforço de reconversão de técnicas de replantação de novos vinhedos, as quais irão conduzir a acréscimos de produtividade.

É também neste mesmo século que a geografia vinícola vai conhecendo uma mudança profunda, tendo a viticultura adquirido uma dimensão económica significativa. Torna-se um sector bem remunerador, que alicia pessoas com posses e sem posses, expandindo-se para terras apropriadas ou não $0^{39}$.

Para o dinamismo deste sector não se pode ignorar a influência do aumento demográfico, o desenvolvimento dos centros urbanos, assim como a facilidade do escoamento do produto. Este é proporcionado pelas boas vias de comunicação e entre estas os cursos de água que assumem um papel relevante nos fluxos comerciais. É pelo rio Mondego, e também pelo Vouga e seu afluente Águeda, que se escoa uma parte significativa dos vinhos da região do Dão e pelo rio Douro os denominados vinhos do Douro. Rios que fazem chegar os produtos aos portos marítimos da Figueira da Foz, de Aveiro e do Porto, para daqui se escoarem para outros mercados, quer nacionais quer estrangeiros.

Estamos, pois, em presença de uma cultura com grande capacidade dinamizadora e transformadora, que traz benefícios de diversa ordem para toda a região, havendo a destacar o papel que desempenhou no alargamento da área cultivada e nos problemas de articulação entre a produção para subsistência e a produção para mercado. É também responsável pela dinamização de um

${ }^{37}$ Orlando Simões, "A Institucionalização da Vitivinicultura Portuguesa: O Caso dos Vinhos de Qualidade”, In Ler História, n 47(2004), pp. 171-193 e António Rafael Amaro, "Produção e Organização do Sector Vitivinícola da Beira Alta(1890-1939)", In Revista de História Económica e Social, $\mathrm{n}^{\mathrm{o}}$ 7, $2^{\mathrm{a}}$ série, 2004, pp. 85-124".

${ }^{38}$ Entre 1867 e 1902 a área nacional de vinha aumentou 110000 hectares. Ver Conceição Andrade Martins, Memória do Vinho do Porto, Lisboa, ICS, 1990, p. 348.

${ }^{39}$ Jaime Reis diz mesmo que nos fins do século XIX se estimava que um hectare com vinha podia dar um rendimento monetário duas a três vezes superior ao de um hectare com cereais. Ver O Atraso Económico Português, 1850-1930, Lisboa, 1993, p. 25. 
pequeno comércio local ou de curta distância, assim como pelo desenvolvimento de pequenos circuitos comerciais, surgindo sobretudo como um dos poucos bens agrícolas que monetariza a economia camponesa, contribuindo, assim, para a integração do mundo rural nos circuitos comerciais. Numa agricultura de subsistência o agricultor conta com a venda do vinho para melhorar o seu orçamento ${ }^{40}$.

Mas a viticultura arrasta consigo outras actividades, sendo mesmo responsável pelo desenvolvimento de alguns sectores industriais subsidiários: tanoaria, serração, cestaria, vidraria, ferraria, etc., transformando-se num foco de atracção demográfica ${ }^{41}$, dadas as consideráveis oportunidades de emprego que proporciona. É o que sobressai dos numeramentos e recenseamentos existentes. As localidades onde se desenvolveu este tipo de actividade são também as mais populosas, registando as mais elevadas densidades demográficas ${ }^{42}$.

É, pois, uma actividade que ocupa intensivamente um considerável número de pessoas durante praticamente todo $\mathrm{o} \mathrm{ano}^{43}$, e às quais é preciso assegurar o sustento diário. Situação que favorece o intercâmbio, os intermediários e o desenvolvimento de uma economia de mercado.

Outra produção que é digna de atenção é a olivicultura. Cultura compensadora que desempenha um importante papel na economia da nossa região, constituindo mesmo «uma importante fonte de receita do agricultor».

Pelas informações encontradas a olivicultura tinha uma presença relevante na nossa região. Nas Memórias Paroquiais fomos encontrando a oliveira praticamente por todo o lado. Também os engenhos para moer a azeitona - os lagares de azeite - eram em grande número, situados junto dos cursos de água. E fomo-la encontrando cultivada de forma contínua - os olivais e também a bordejar campos de outros cultivos, mas sempre associada a outras culturas. Mas apesar de possuir condições geoclimáticas favoráveis, esta não é

\footnotetext{
${ }^{40}$ Albert Silbert, Le Portugal Mediterranéen à la Fin de l'Ancien Régime, Lisboa, INIC, $2^{a}$ edição, 1978, vol. I, p. 121.

${ }^{41}$ Camilo J. Fernàndez Cortizo, "La emigración gallega a la provincial portuguesa de Tras-os-Montes y Alto Douro (1700-1850): evolución temporal, tipologia y localidades de partida y de destino" in Douro - Estudos e Documentos, Porto, GEHVID, n ${ }^{\circ} 22,2007$, pp. 79-112.

${ }^{42}$ Em 1864, Lamego, Resende e Armamar, como áreas fortemente vinhateiras registam a mais elevada densidade populacional do nosso território, com 153, 151 e 101 habitantes por $\mathrm{km} 2$ respectivamente, enquanto Viseu que se lhes segue tem 94. In: X Recenseamento Geral da População, Tomo I, Vol. 1º, 1960, pp. 108 e 111.

${ }^{43}$ Orlando Ribeiro, Geografia de Portugal, Lisboa, Edições Sá da Costa, Vol. IV, 1991, p. 1013; Roger Dion, Histoire de la Vigne et du Vin en France des Origines au XIX siécle, Paris, 1959 , p. 33.
} 
a província com as quotas de produção mais elevadas. Era apenas responsável por 11,9\% da produção nacional, em 1901-1904, ficando bem atrás do Ribatejo, do Alentejo e da Beira Baixa.

Estamos em presença de um produto - o azeite - que tem uma grande procura, dada a sua diversificada utilização. Servia como alimento e condimento na cozinha, servia para iluminar, sustentando o pavio da candeia, era imprescindível na indústria saponífera e era também usado como amaciador na manufactura dos lanifícios, nas fases de cardagem e de fiação.

Para além do largo consumo interno, era também um produto que entrava no circuito exportador.

Por tudo isto, a oliveira tornou-se uma árvore estimada, assistindo-se à sua expansão, como os vários testemunhos encontrados confirmam. Entre 1795 e 1806, e também no ano de 1824, deparamo-nos, nas contas do Mosteiro de Jesus de Viseu, com montantes elevados dispendidos na aquisição de «estacas de oliveira», para plantar em terra desbravada. E os visitadores da Comenda de Malta também nos dão notícias explícitas da plantação de novos olivais em alguns dos seus domínios, nos anos de 1744, 1766 e 1767.

Sinais dessa progressão temo-los também por meados do século XIX. No distrito da Guarda esse movimento é testemunhado, em 1856, no Relatório da Sociedade Agrícola dessa cidade, ao afirmar-se que «N'este Districto a plantação de oliveiras tem sido generalisada, de forma que se tem para ellas dedicado o terreno que lhes é proprio, e o cultivador tem para ali voltado todas as suas vistas, no intuito provavel de um bom lucro, maximo comparado com a pequenez da despeza ${ }^{44}$. Expansão essa que é confirmada pelos valores produzidos entre 1874 e 1910, que passaram de 21646 para 32413 hectolitros - um aumento de 49,5\%. E dos quantitativos aí produzidos, $59 \%$ pertencem ao distrito da Guarda e 41\% ao de Viseu, em 1874, e no ano de 1910 esse valor reparte-se respectivamente por $56,5 \%$ e $43,5 \%$. Valores que confirmam ser o distrito da Guarda aquele que mais produz.

Pensamos que esta evolução não é estranha ao comportamento dos preços que iniciam uma fase ascendente a partir de meados do século ${ }^{45}$, tornando-se um factor encorajador, transmitindo confiança aos produtores a intensificarem o seu

44 «Relatório da Sociedade Agricola da Guarda», in BMOPCI, n4 de Abril de 1856, p. 212, citado por David Justino, A Formação do Espaço Económico Nacional. Portugal 1810-1913, Lisboa, Vega ed., vol. II, 1989, p. 115.

${ }^{45}$ Vitorino Magalhães Godinho, Prix et Monnaies au Portugal. Paris, Librairie Armand Colin, 1955 
cultivo. De salientar também a melhoria que se regista a nível dos transportes, facilitando o seu escoamento.

Outro sector com que nos fomos deparando, e que também contribuiu para dinamizar a actividade mercantil no mundo rural, foi o da fruticultura. Árvores de fruto de várias espécies fomo-las encontrando disseminadas pelo nosso espaço. Sector compensador, mas de difícil avaliação quantitativa. A maior parte das frutas produzidas destinava-se apenas ao auto-consumo ou ao consumo local. Só uma pequena parte se destinava a satisfazer a procura de outras localidades mais afastadas, como a cidade do Porto, Lisboa ou Algarve.

Várias são as árvores de fruto que nos aparecem: macieiras, pereiras, ameixoeiras, abrunheiros, cerejeiras, figueiras, pessegueiros, nogueiras, marmeleiros, amendoeiras, ginjeiras, laranjeiras e castanheiros ${ }^{46}$. Quanto às macieiras encontrámos referências a várias qualidades, sendo a maçã uma das frutas que mais se produzem e mais se vendem. Assim acontece com os "verdiais" produzidos, por exemplo, nas freguesias de Serrazes (Lafões) e de Torredeita (Viseu), que são exportados em grande quantidade " $\mathrm{p}^{\mathrm{a}}$ difrentes partes deste Reino como $\mathrm{p}^{\mathrm{a}}$ a corte de $\mathrm{Lx}^{\mathrm{a}}{ }^{a}{ }_{47}$.

"Fruta de espinho"(laranjas) encontramo-la também em várias localidades, como, por exemplo, S. João da Pesqueira, em algumas localidades de Lamego, na região de Lafões, em algumas freguesias do concelho de Viseu e principalmente no concelho de Besteiros. Fruta esta que era também enviada para Lisboa.

Temos ainda notícias sobre a transformação em compota de algumas frutas, que depois eram exportadas. De entre estas merece uma referência especial as conservas de pêra pigarça feitas pelas irmãs do Mosteiro das Chagas de Lamego, as quais eram enviadas para muitas partes do Reino "depois de cobertas e dulcificadas".

Fazem também parte dos circuitos comerciais os figos secos, as passas de uva e as amêndoas produzidas no nosso espaço. Melões e melancias são dois frutos que entram nas trocas comerciais, sendo mesmo exportados para os centros urbanos, como, por exemplo, a cidade do Porto, escoados através do rio Douro. Por fim, uma referência ao castanheiro que nos merece um destaque especial, tornando-se uma presença constante nas terras beirãs. $\mathrm{O}$ seu fruto

${ }^{46}$ Sobre fruticultura ver João Nunes de Oliveira, A Beira Alta de 1700 a 1840. Gentes e Subsistências, pp. 123-128; António Rafael Amaro, Economia e Desenvolvimento na Beira Alta, pp. 164-165.

${ }^{47}$ Instituto Arquivos Nacionais/Torre do Tombo (Lisboa), Memórias Paroquiais, Vol. 42, mem. 408 e vol. 43, mem. 441. Ver também Duarte Nunez do Leão, Descripção ... cit, fl. 66v. 
- a castanha - constituía um alimento básico das populações, podendo manter-se verde ou seca todo o ano. Mas não se pense que ela se confina apenas ao meio rural. Desce também à cidade, exportando-se seca para Lisboa e para o Algarve ${ }^{48}$.

\section{Produções industriais: o sumagre, a amoreira e o linho}

O progresso e diversificação agrícola está também relacionado com a necessidade de matérias-primas e alguns ingredientes para a indústria.

Dada a precária economia do camponês, e para fazer face à insuficiência dos recursos provenientes da agricultura, as pessoas fiam, tecem, curtem e tingem em suas casas, produzindo ou colhendo a matéria-prima necessária a tais tarefas. Para além da lã, também as culturas do linho, da amoreira e do sumagre, entre outras, se espalham pela nossa região.

A actividade artesanal ligada ao trabalho das peles estava disseminada pelo nosso espaço. Mas antes de trabalhá-las era preciso preparar os couros, curtindo-os. O curtimento constituía mais um labor que desencadeava outra actividade: o cultivo, apanha e moagem das folhas e casca do sumagre. Planta essa que, para além de cultivada, cresce principalmente nos lugares pedregosos e nas margens dos campos e dos caminhos.

Encontramos a sua menção em algumas freguesias, nas Memórias Paroquiais, assim como num manuscrito sobre o Douro Superior, de $1790^{49}$. Assim, através do primeiro documento ficámos a saber, por exemplo, que em Valdigem (termo de Lamego), Muxagata (termo de Fornos de Algodres) e em S. João da Pesqueira e seu termo, "o sumagre também atingia bons níveis de produção" e em Freixo de Numão e seu termo havia "muitos sumagres que rendiam bom dinheiro" 50 . Na vila de S. João da Pesqueira havia mesmo, em 1774, atafonas para o moer ${ }^{51}$.

Nesta nossa "viagem" pela Beira Alta deparamo-nos também com o cultivo da amoreira, árvore imprescindível ao desenvolvimento da sericicultura, dado que as suas folhas constituem o único alimento do bichinho produtor da tão

${ }^{48}$ L.A. Rebello da Silva, Memoria sobre a População e a Agricultura de Portugal desde a Fundação da Monarchia até 1865, Parte I (1097-1640), Lisboa, Imprensa Nacional, 1868, p. 253.

${ }^{49}$ Aurélio de Oliveira e Natália Fauvrelle da Costa, "Um Manuscrito Inédito Sobre o Douro Superior em Finais do Século XVIII”, in Douro - Estudos e Documentos, vol. I (1), $1996\left(1^{\circ}\right)$, pp. 196-258.

${ }^{50}$ Instituto Arquivos Nacionais/Torre doTombo (Lisboa), Memórias Paroquiais, vol. 16, mem. 187.

${ }^{51}$ Arquivo da Câmara Municipal de S. João da Pesqueira, Livro de Acordãos do ano de 1774. 
delicada e apreciada fibra. Para além de algumas informações facultadas pelas Memórias Paroquiais, também as actas de algumas Câmaras (Trancoso, Lamego e Penalva do Castelo) nos dão a conhecer a importância que o poder - quer o Municipal quer o Central, este em Lisboa - lhe dedicava, ao publicar algumas medidas incentivadoras à expansão da sua plantação. Atenção que não era apenas dirigida a esta fase do processo, mas também ao modo como devia ser executada a fiação, como aliás aconteceu, em 1776, na vila de Trancoso. Existindo nesta vila, e em todo o seu termo, muitas fiandeiras de seda, e porque o seu trabalho não fosse perfeito, decidiu-se "esclarecer e ensinar as pessoas, porque o trabalho mais bem feito proporcionava maiores lucros, tanto para quem fiava como para quem utilizava o fio" 52 . E para além da fiação manual, também laborava na localidade de Avelãs da Ribeira uma "fábrica de seda"53.

Entre 1776 e 1803 encontramos, nas actas da Câmara de Lamego, várias referências a provisões que determinam o plantio de amoreiras, medida que deve ser vigiada pelos oficiais da Câmara. E, na sessão Camarária de 23 de Julho de 1803, nomeia-se um inspector para as plantações e determina-se ainda a criação de "viveiros de amoreiras" para depois se transplantarem ${ }^{54}$. Muxagata (termo de Fornos de Algodres), Lalim (termo de Lamego) e Casteição (termo da Meda) sobressaem também, nas Memórias Paroquiais, como centros de "produção de seda".

O linho é outro cultivo que tem uma forte presença, destacando-se as terras de Riba-Côa como as que mais produzem ${ }^{55}$. O linho, planta oleaginosa e fibrácea, era importante na medicina e sobretudo no vestuário, já que constituía a matéria-prima para a «indústria» da roupa branca. Para além do fabrico de panos, o óleo extraído da sua semente empregava-se na iluminação e o bagaço proveniente da prensagem da sua semente servia de alimento ao gado.

\section{Montes, bosques e espaços de fruição colectiva}

Também os montes, bosques e espaços de fruição colectiva merecem a nossa atenção porque têm um elevado peso na vida e na economia das comunidades locais. A sua presença era frequente no quotidiano das comunidades aldeãs,

${ }^{52}$ Arquivo da Câmara Municipal de Trancoso, Livro de Acordãos de 1775 a 1779, fl. 35 e $35 \mathrm{v}$.

${ }^{53}$ Arquivo da Câmara Municipal de Trancoso, Livro de Acordãos de 1779 a 1781, fl. 72.

${ }^{54}$ Arquivo Histórico da Câmara Municipal de Lamego, Livro das Leis, Decretos e Avisos, Providências vindas à Câmara desta cidade de Lamego no ano de 1802, fl. 64v, 65 e 300 a 309.

55 João Marinho dos Santos, O Concelho de Almeida. Esboço Histórico-Sociológico, Viseu, Palimage ed., 2005, pp. 142-143. 
tornando-se um suporte fundamental do sistema agrário, dadas as suas múltiplas possibilidades de uso, ajudando o camponês a viver e a sobreviver. A sua valia não pode ser ignorada ou desvalorizada ${ }^{56}$. Valia que se radica tanto nas possibilidades do seu aproveitamento directo - pastoreio, apanha e corte de lenha, obtenção de madeira, cultivo de algumas parcelas, apanha de mato para estrume - como na obtenção de recursos financeiros para os municípios ${ }^{57}$. A sua relevância sócio-económica é difícil de quantificar, por causa dos diversos aproveitamentos que permitia e das diversas actividades que sustentava. Mas temos de reconhecer que eram espaços que se tornavam fundamentais para os núcleos urbanos, já que estes eram consumidores sistemáticos de madeira, lenha e carvão, o que constituía um modo de vida para aqueles que se dedicavam à sua venda ${ }^{58}$.

Para além da lenha e do carvão também a casca de algumas árvores era fundamental para o curtimento de peles, pelo tanino que possuía, tornando-se um motor da actividade artesanal e contribuindo também para aumentar a procura de tais produtos.

\section{Pecuária}

Outra actividade que mantinha estreitas relações de interdependência com a agricultura era a pecuária. Sector imprescindível ao mundo rural, estava ligado à produtividade dos campos, quer através do estrume, quer da força de tracção disponibilizada por bovídeos, gado cavalar, muar e asinino. Era destes animais que dependiam as lavras dos campos e os transportes.

Como coadjuvante do homem, a criação de gado fornece um rendimento regular, seguro e compensador, tendo uma grande influência nas economias locais e da própria região. Não dispomos de dados numéricos fidedignos acerca dos quantitativos de gado, mas através da leitura das Memórias Paroquiais foi possível constatar que raras eram as localidades que não tinham gados de lã

${ }^{56}$ Ofelia Rey Castelao, "Montes, Bosques y Zonas Comunales: Aprovechamientos agrícola-ganaderos, florestales y cinegéticos", in Francisco José Aranda Pérez (coordinador), El Mundo Rural En La España Moderna, Cuenca, Ediciones de la Universidad de Castilla-La Mancha, 2004, pp. 907-964.

57 João Nunes de Oliveira, A Beira Alta ..., cit., pp. 162-165.

${ }^{58} \mathrm{Na}$ vila de Lalim a maior parte dos montes “... são infrutiferos, pq so dam lenha a que chamam urge a que costumam cortar os moradores desta freg ${ }^{\mathrm{a}}$ para ir vender todos os dias à cidade de Lamego". In: Instituto Arquivos Nacionais/Torre do Tombo (Lisboa), Memórias Paroquiais, Vol. 19, mem. 26. 
(ou de pêlo) e de trabalho para o arado $^{59}$. E no final do século XIX, em 1890, o Intendente da Pecuária da Beira Alta afirmava que uma das suas primeiras riquezas era a criação de gado - vacum, suíno e principalmente lanígero favorecida quer pela condição montanhosa de grande parte do seu espaço, quer pela sua aptidão "ervosa”. E para ele é da criação e venda deste gado que os lavradores e os rendeiros auferem os maiores lucros ${ }^{60}$. Criação de gado que deve o seu crescimento também à expansão do milho grosso, que é responsável pelo desenvolvimento da rotação campo-prado.

A actividade pecuária proporcionava um conjunto de produtos de grande valor e utilidade: as crias, a carne, os couros, os produtos lácteos, a lã e o estrume. E era também responsável pelo funcionamento de dois sectores industriais, fortemente disseminados na nossa região: os têxteis e os curtumes.

Uma outra actividade artesanal, dependente da pecuária, que contribuía também para a dinamização do comércio, e que não podemos deixar de mencionar, é a produção de queijo e em menor escala a de manteiga ${ }^{61}$.

A criação de gado depende da largueza e abundância das pastagens. Largueza que é maior na parte oriental, dado que estamos em presença de uma área pouco povoada, sendo a sua densidade demográfica bastante baixa: quase metade da registada na parte ocidental ${ }^{62}$. Há que ter em conta que a Beira Interior orientou a sua agricultura para uma quase monocultura cerealífera - a do centeio - e para a criação de gado, razão pela qual encontramos bastas referências, nas Memórias Paroquiais, à criação de gado lanígero, particularmente em Castelo Melhor, Castelo Bom, Castelo Rodrigo, Castelo Mendo, Escalhão, Sabugal, Pinhel, Almendra, etc.

$\mathrm{Na}$ segunda metade do século XIX regista-se um aumento da produção pecuária ${ }^{63}$, devido à crescente procura nacional e internacional e à melhoria e expansão das vias de comunicação. A abertura da linha férrea da Beira Alta é de 1882 e irá facilitar o escoamento dos produtos da região para mercados mais longínquos.

${ }^{59}$ Instituto Arquivos Nacionais/Torre do Tombo (Lisboa), Memórias Paroquiais, Vol. 3 , mem. 12 .

${ }^{60}$ António Rafael Amaro, Economia..., cit., pp. 241-242.

${ }^{61}$ Sobre o rendimento do gado ovino, ver Margarida Sobral Neto, "A Vida Económica e Social de Gouveia na Época Moderna. Um Contributo para o seu Estudo”, In: Revista Portuguesa de História, Tomo XXXV (2001-2002), pp. 254-256.

${ }^{62}$ A densidade demográfica era em 1864 e em 1900, no distrito da Guarda de 39,0 e de $48,1 \mathrm{habs} / \mathrm{km}^{2}$ respectivamente e no distrito de Viseu de 72,9 e de 81,7. In: X Recenseamento Geral da População, Tomo I, Vol. 1 ${ }^{\circ}$ 1960, pp. 108 e 111.

${ }^{63}$ António Rafael Amaro, Economia..., cit., pp. 241-257; Hélder Adegar Fonseca, O Alentejo no Século XIX. Economia e Atitudes Económicas, Lisboa, Edições da IN/CM, 1996. 


\section{A realidade em Espanha}

E o que se foi passando no país vizinho ${ }^{64}$ durante este período? A Espanha caracteriza-se pela heterogeneidade. Não é uma realidade uniforme. Existem agriculturas muito diversas, apresentando por isso, as diversas regiões, níveis e formas de desenvolvimento muito distintas. Tal como do lado de cá da fronteira, uma parte substancial do espaço agrícola continuou votado às culturas cerealíferas, que no entanto foram registando crescimentos de produção. Mas também se ia assistindo a inovações, a diversos níveis, e à intensificação no cultivo de bens mais virados para o mercado.

As produções apresentam-se mais estáveis no interior espanhol do que nas zonas costeiras. Os cultivos no interior mantiveram-se, até muito tarde, sem mudanças significativas. Mudanças que se tornaram mais perspectíveis numas regiões do que noutras, no decorrer do século XVIII, tendo-se intensificado no século seguinte. Desde o século XVIII que se vai assistindo à perda de importância de alguns cereais de sequeiro, assistindo-se à expansão em algumas regiões de novos cultivos como o maís, a batata e o arroz. Aposta-se numa agricultura de regadio, aproveitando-se as potencialidades dos vales dos rios.

Transformações e inovações produtivas que se ficaram a dever a vários factores como a desamortização, as melhorias nas condições de transporte, que iriam contribuir para a formação do mercado interno e para facilitar o

${ }^{64}$ Sobre o processo evolutivo da agricultura em Espanha nos séculos XVIII e XIX tivemos em conta os trabalhos dos seguintes autores: Gonzalo Anes, La Economía Española al Final del Antiguo Régimen, Madrid, Alianza Editorial, 1982, pp. XVIII-XLV; Jaime García-Lombardero, "Aportación al Estudio del Sector Agrario en la Galicia del Siglo XVIII. Un Contraste con Cataluña", In Jordi Nadal y Gabriel Tortella(ed.), Agricultura, Comercio Colonial y Crecimiento Económico en la España Contemporánea, Barcelona, Editorial Ariel, 1974, pp. 49-55; Ramon Garrabou, Carlos Barciela y J.I. Jiménez Blanco(ed), Historia Agraria de la España Contemporánea, vol. 3, Barcelona, Editorial Crítica, 1986; Samuel Garrido, Canem Gentil. L'Evolució de les Estructures Agràries a la Plana de Castelló (1750-1930), Castellón de la Plana, 2004; Pedro Schwartz Giron (coordinador), Ensayos sobre la Economia Española a Mediados del Siglo XIX, Madrid, Ariel, 1970, pp. 235-263; Miguel Ángel Melón Jiménez, Extremadura en el Antiguo Regimen. Economia y Sociedad en Tierras de Cáceres, 1700-1814, Badajoz, 1989, pp. 75-129; Ramón Garrabou, "Las Transformaciones Agrarias durante los Siglos XIX y XX", In Jordi Nadal y Gabriel Tortella (eds), Agricultura, Comercio Colonial y Crecimiento Económico en la España Contemporánea, Barcelona, Editorial Ariel, 1974,pp. 206-229; L. M. Enciso Recio, A. González Enciso, História de España, Vol.10 - Los Borbones en el Siglo XVIII(1700-1808), Madrid, Editorial Gredos, 1991,pp. 141-167. 
escoamento, a expansão do regadio, uma maior procura, devida ao crescimento sustentado da população desde princípios do século XVIII, assim como a subida de preços e ainda a introdução de novas técnicas.

A desamortização, tida como «o grande fenómeno do século XIX», provoca mudanças na estrutura da propriedade e no regime de cultivos, permitindo o aumento da área cultivada e uma exploração mais racional e com maior eficácia, assistindo-se a um aumento da produção e da produtividade.

Assiste-se então a um intenso processo de desflorestação e de arroteamentos.

Mudanças que tinham sido já facilitadas e incentivadas com a publicação, a partir de meados do século XVIII, de nova legislação destinada a eliminar, ou pelo menos a corrigir alguns dos entraves existentes que dificultavam o desenvolvimento agrícola.

O ritmo da mudança não foi uniforme no que se refere a produções e regiões. Foi sobressaindo e afirmando-se um subsector agrícola muito mais prometedor do que a tradicional cerealicultura, assistindo-se ao desenvolvimento de um agricultura muito mais rentável e virada para o mercado. Produtos como os vinhos, o azeite, a fruticultura e a horticultura aparecem entre as exportações, já em meados do século XIX. Neste século avança-se significativamente na formação de um mercado interno de bens alimentares e assiste-se a um impulso exportador, o que estimulou o processo de especialização.

No litoral mediterrâneo, antes mesmo do século XIX, havia-se desenvolvido uma agricultura frutícola e hortícola muito virada para o mercado e que se foi tornando compensadora. $\mathrm{O}$ vinho tornou-se um dos produtos exportáveis mais importantes, tendo aumentado espectacularmente as exportações durante a primeira metade do século XIX.

Mas para além das produções da agricultura mediterrânea, também os produtos pecuários e florestais mostram potencial exportador. As regiões com facilidade de saída para o mar desenvolvem uma agricultura especializada e mais dirigida para os mercados externos. Entre essas regiões destacam-se Aragão, Valência, e principalmente a Catalunha, tendo em finais do século XVIII uma agricultura bastante diversificada, desenvolvida e comercializável. Na Extremadura, para além do aumento da produção cerealífera, assiste-se a uma diversificação e intensificação de outros cultivos como a batata, as leguminosas, as plantas industriais e a ganadaria. Também o olival aí se expande, aproveitando as condições edafológicas favoráveis. Olival que foi um dos protagonistas da expansão agrária oitocentista nas áreas catalã, aragonesa e andaluza. A Cantábria e Navarra desenvolvem a criação de gado, dadas as condições favoráveis que aí existem para o desenvolvimento de pastagens. 


\section{Em síntese}

Da documentação e bibliografia consultada não se pode concluir por uma situação de imobilismo da agricultura da nossa região. Vários são os sinais de alguma modernidade que fomos encontrando. Sinais que são mais frequentes e notórios na sub-região ocidental e na área norte-beirã/duriense do que na sub-região oriental.

No decurso destes duzentos anos podem perspectivar-se quatro tempos, caracterizados pelo aprofundamento de algumas mudanças. O primeiro estará ligado à expansão do maís, particularmente no decurso do século XVIII; o segundo tem nas Invasões Francesas (1807/1811) o seu responsável; o terceiro está fortemente ligado à revolução liberal, pelo seu ataque profundo às estruturas feudais, e o quarto tempo está ligado ao fontismo (segunda metade do século XIX), período de desenvolvimento dos transportes e de tomada de medidas que puseram definitivamente fim a algumas excrescências feudais que teimavam em persistir.

No que respeita ao primeiro tempo, destaca-se a acção e efeitos que a expansão do maís implicou e a que já fizemos referência. Mas este é também um período ligado a um aumento das vedações e dos arroteamentos de terras comunais, à plantação de culturas mais viradas para o mercado - pomares, olivais e vinhas - e a diversas benfeitorias destinadas a aumentar a eficiência produtiva, como a obtenção de água, chegando-se mesmo a desviar alguns rios por um curso novo para abastecer as novas terras arroteadas e as novas plantações $^{65}$. São também publicadas, particularmente na segunda metade do século XVIII e início do XIX, várias medidas e providências com vista a eliminar

${ }^{65}$ Entre 1744 e 1776 encontrámos várias notícias das muitas benfeitorias que se iam realizando em vários domínios pertencentes à Ordem de Malta - Rossas, Barrô, Ansemil, Fontelo - assim como nas imediações de Lamego e de S. João da Pesqueira. Dá-se conta do desbravamento de terras de mato e do desmanchar de terras ocupadas por culturas pouco rentáveis, plantando-se de novo vinhas, olivais e pomares. Encontramos também notícias sobre vedações que foram sendo feitas, assim como a obras de irrigação, chegando mesmo, na comenda de Ansemil, a desviar-se o rio Outeiro por um novo curso para regar as "terras de boa cultura", que iam sendo arroteadas. In:Instituto Arquivos Nacionais/Torre do Tombo (Lisboa), Ordem de Malta, Livros 16, 18, 19 e 20. Sobre a problemática de terras comunais e de arroteamentos, ver Maria Margarida Sobral Neto, "Uma Provisão sobre Foros e Baldios: problemas referentes a terras de «logradouro comum» na região de Coimbra, no século XVIII", In Revista de História Económica e Social, $n^{\circ} 14,1984$, pp. 91-99. 
alguns entraves denunciados por vários autores, e assim poder contribuir para a dinamização da nossa atrasada agricultura ${ }^{66}$.

No segundo período, marcado pelas invasões francesas, registaram-se também algumas mudanças importantes. Os momentos de instabilidade político-social e de crise económica, como os que se viveram então, acabaram por se tornar favoráveis a alterações no sistema de aproveitamento dos solos e no sistema de produção, o que contribuiria para um enfraquecimento das estruturas de tipo feudal e para um avanço da agricultura. É neste contexto que assistimos a determinações emanadas de Lisboa, pela Intendência Geral da Polícia da Corte do Reino, ordenando às Câmaras a tomada de medidas para promover o aumento da produção e cuja execução pelos agricultores seria vigiada pelo juiz do povo. Entre essas medidas destaca-se a promoção do cultivo da batata, assim como de nabos, favas, ervilhas e de outros géneros próprios para sementeiras de Outono. É também determinada a sementeira de ervas e o cultivo da ervilhaca para proporcionar o aumento da criação de gado, particularmente do bovino, por ser tão necessário e útil aos trabalhos agrícolas e aos transportes ${ }^{67}$. É neste contexto que também se proíbe o abate de vitelas. E em 1807 ordena-se às Câmaras que mandem semear "as terras deste anno e outras mais que o posão ser sem desarranjo da Economia Rural" ${ }^{68}$. O que pode significar o desrespeito pelo pousio.

Mudanças que iriam aprofundar-se significativamente com a Revolução Liberal de 1820. Criaram-se então as condições políticas propícias para uma reforma profunda, que veio praticamente a ser iniciada com as Cortes Constituintes e aprofundada por Mouzinho da Silveira. A partir de 1834 vai-se criando uma nova estrutura sócio-económica liberta de alguns dos principais entraves senhoriais, apesar de o desaparecimento efectivo da estrutura feudal se processar de um modo muito lento, como sobressai de várias obras publicadas ${ }^{69}$.

${ }^{66}$ Margarida Sobral Neto, Terra e Conflito. Região de Coimbra, 1700-1834, Viseu, Palimage Ed., 1997, pp. 335-339 e 359. Joaquim Romero Magalhães, "Alguns Aspectos da Produção Agrícola no Algarve: Fins do Século XVIII - Princípios do Século XIX”, in Revista Portuguesa de História, Tomo XXII, Coimbra, 1987, pp. 1-29.

${ }^{67}$ Os mesmos documentos referidos na nota 22.

${ }^{68}$ Arquivo Histórico da Câmara Municipal de Lamego, Livro que hade servir para os Actos de Camara desta cidade de Lamego, 1805 a 1808, fl. 82v e 83.

${ }^{69}$ Miriam Halpern Pereira, Livre Câmbio e Desenvolvimento Económico. Portugal na segunda metade do século XIX, Lisboa, Cosmos, 1971, pp. 14-23 e 317-322; Maria Margarida Sobral Neto, "A desagregação das estruturas do Antigo Regime: alguns indicadores", In: Do Antigo Regime ao Liberalismo, 1750-1850 (Organização de Fernando Marques da Costa e outros), Lisboa, Vega, 1989, pp. 251-258; Hélder Adegar da Fonseca, “A propriedade da terra em Portugal 1750-1850: alguns aspectos para uma síntese”, in Do Antigo Regime ao Liberalismo, 
A actividade legislativa das cortes de 1822 e principalmente de 1834 teve como objectivo principal a supressão dos privilégios feudais e eclesiásticos e a alteração jurídica da propriedade, o que terá contribuído para dar um forte impulso transformador às estruturas agrárias, criando condições mais favoráveis ao progresso do sector agrícola.

Quanto ao modelo regenerador, ter-se-á empenhado na modernização do país. Período em que se assiste ao aumento das exportações de alguns bens agrícolas e ao lançamento das infra-estruturas dos transportes e comunicações, observando-se o alargamento da superfície cultivada.

Na segunda metade do século XIX o movimento de novas arroteias aumenta significativamente, assistindo-se a um combate aos incultos, ao desbravamento de novas terras e à supressão dos direitos comunitários e das pastagens comuns ${ }^{70}$. Melhorias que contam ainda com o aperfeiçoamento das técnicas de cultivo e dos instrumentos de trabalho.

A alta simultânea dos preços dos cereais e da carne de 1847 a 1870 motiva os agricultores para a tentativa de aumentar as suas produções. Exportações e aumento da urbanização incentivam a uma melhor ocupação dos solos. Eis um estímulo à produção. É que a abertura de vias de comunicação e o desenvolvimento dos transportes (na época fontista) facilitava o escoamento e reduzia o isolamento de alguns espaços, incentivando a implantação de novas actividades produtivas.

Do que fica dito sobressaem sinais evidentes de modernidade, particularmente na parte ocidental do nosso território. Para além da expansão de algumas produções comercializáveis - vinho, azeite, frutas, milho, batata - assiste-se ao alargamento e diversificação do património agrário e a alguns progressos técnicos, como o regadio e a redução das terras incultas. Mas apesar das mudanças, continua a registar-se uma dominância das produções para auto-consumo.

1750-1850, Lisboa, Vega, 1989, pp. 213-240. Vitorino Magalhães Godinho, Estrutura da Antiga Sociedade Portuguesa, Lisboa, Arcádia Editora, s/d.

${ }^{70}$ Movimento de arroteias, em toda a Beira Alta, que é confirmado por João Mousinho de Albuquerque, em 1856, ao dizer:"os roteamentos invadem já os terrenos de suas escaças e restringidas mattas, e charnecas cuja roteação indiscreta e mal dirigida, faz já muito sensivel a falta das madeiras para os differentes misteres da vida social; apropriando esses restantes baldios, refrigerio unico da classe trabalhadora e industrial não proprietaria", In «Roteamentos», in Journal da Sociedade Agricola do Porto, vol. I, 1856, p. 142; Sobre o mesmo assunto ver também António Rafael Amaro, Economia..., cit., pp. 112-114. 
Torna-se bem evidente a existência de uma agricultura dual: uma que mostra grande dinamismo e outra que é marcada pelo quase imobilismo, esta com forte influência sobre aquela, dificultando a modernização. É que a produção cerealífera constituía a base da produção agrícola e da subsistência das populações e condicionou, em boa medida, a evolução de todo o sector agrário. Mas, apesar disso, a nossa paisagem rural foi evoluindo como o demonstram a difusão de novas culturas, a expansão da área cultivada e a alteração na hierarquização das produções.

Pensamos que muitos dos arroteamentos estariam ligados a pomares, olivais e vinhas, culturas estas mais vantajosas e compensatórias dos custos com os arroteamentos, dada a sua vocação (mais) comercial. Mas esses arroteamentos estariam também ligados a culturas de regadio, como o milho grosso, ou mesmo a batata.

E não podemos esquecer, finalmente, que as mudanças registadas acabam por favorecer a difusão de uma agricultura intensiva, apesar de se processarem de uma forma lenta, ou mesmo muito lenta. 
